\title{
Association of perceived neighborhood problems and census tract income with poor self-rated health in adults: a multilevel approach
}

\author{
Associação da percepção de problemas na vizinhança \\ e renda de setor censitário com autoavaliação \\ negativa de saúde em adultos: uma \\ abordagem multinível
}

\begin{abstract}
Asociación de la percepción de problemas en barrios y renta de las circunscripciones censales con la autoevaluación negativa de salud en adultos: un enfoque multinivel
\end{abstract}

\footnotetext{
1 Departamento de Nutrição, Universidade Federal do Paraná, Curitiba, Brasil. 2 Programa de Pós-

Graduação em Saúde

Coletiva, Universidade

Federal de Santa Catarina,

Flórinopolis, Brasil.

3 School of Public Health,

Drexel University,

Philadelphia, U.S.A.

${ }^{4}$ Universidade de São Paulo,

São Paulo, Brasil.

5 School of Dentistry,

University of Adelaide,

Adelaide, Australia.

\author{
Correspondence \\ D. A. Höfelmann \\ Departamento de Nutrição, \\ Universidade Federal \\ do Paraná. \\ Av. Prefeito Lothário Meissner \\ 632, Curitiba, PR 80210-170, \\ Brasil. \\ doroteia.hofelmann@ufpr.br
}

\begin{abstract}
Neighborhood problems constitute sources of chronic stress that may increase the risk of poor self-rated health. The associations of census tract level income and perceived neighborhood problems with self-rated health were examined in Florianópolis, Santa Catarina State, Brazil (1,720 adults). Odds ratios (OR) and their 95\% confidence intervals (95\%CI) of poor self-rated health were estimated through multilevel models. Residents in census tracts in the lower and intermediate tertiles of income reported poorer health than those in the highest tertile. OR of reporting poorer health was 2.44 (95\%CI: 2.352.54) in the higher tertile of social disorder (adjusting for mental health). The chances of reporting the poorer health with neighborhood problems ranged from 1.07 (95\%CI: 1.03-1.11) to 2.02 (95\%CI: 1.95-2.10) for the higher tertile of social disorder (physical health) and physical problem (health-related variables). Perceived neighborhood problems were independently associated with poor health. The perception of a neighborhood among its residents should be considered by health policymakers.
\end{abstract}

Housing; Residence Characteristics; Socioeconomic Factors; Urban Health
Doroteia Aparecida Höfelmann 1,2 Ana V. Diez Roux 3 José Leopoldo Ferreira Antunes 4 Marco Aurélio Peres 2,5

\section{Resumo}

Problemas na vizinhança representam fontes de estresse crônico que podem aumentar o risco de autoavaliação de saúde negativa. A associação entre renda do setor censitário e problemas na vizinhança com a autoavaliação de saúde foi examinada em Florianópolis, Santa Catarina, Brasil (1.720 adultos). Razões de chance e seus intervalos de 95\% de confiança (IC95\%) de autoavaliação de saúde negativa foram estimados por meio de modelos multiníveis. Residentes em setores censitários de renda baixa e intermediária referiram pior saúde do que aqueles do tercil mais elevado. A razão de chance de referir pior saúde foi de 2,44 (IC95\%: 2,35-2,54) no tercil com mais problemas de desordem social na vizinhança (ajustando para saúde mental). A chance de referir pior saúde com problemas na vizinhança variou de 1,07 (IC95\%: 1,03-1,11) a 2,02 (IC95\%: 1,95-2,10) para o tercil mais elevado de desordem social (saúde física) $e$ problemas físicos na vizinhança (relacionados à saúde). A percepção de problemas na vizinhança foi independentemente associada à pior saúde, $e$ deve ser considerada por aqueles que elaboram as políticas.

Habitação; Distribuição Espacial da População; Fatores Socioeconômicos; Saúde Urbana 


\section{Introduction}

Self-rated health represents a multidimensional construct that encompasses physical, mental, and social wellbeing. This variable consistently predicts morbidity 1 , use of clinical services, health deterioration, and mortality, even after adjusting for other covariates 2 , and reflects the cumulative impact of manifested and subclinical diseases ${ }^{3}$.

Associations between self-rated health and measures of socioeconomic status are well established 4,5. Individuals from lower socioeconomic position groups experience worse health and presenthigher rates of deterioration of their health over the course of their lives when compared with those who belong to wealthier groups 5,6.

There has been growing interest in the study of the association between the characteristics of places in which people live and health, over and above the impact of individual-level factors. People living in more deprived neighborhoods tend to have poorer health than those in wealthier ones 7,8,9 and some of these findings have been supported by longitudinal studies 10 .

Neighborhood problems constitute sources of chronic stress that may increase the risk of poor health 7 . Communities with lower income, particularly in urban areas, often experience higher levels of crime, unemployment and violence all of which may be sources of chronic stress. Previous studies have demonstrated that residing in neighborhoods perceived to be characterized by social disorder and socioeconomic disadvantages is associated with higher levels of depression 11, hopelessness 12, distress, and more broadly, a poorer assessment of overall health 13 . These communities may also encounter higher levels of environmental stressors, such as noxious chemicals and pollution, which may have health implications 14 . The neighborhood also impacts on health through access to resources related to diet and physical activity including access to healthy foods, environments suitable for walking and recreational facilities. An alternative, and particularly important, pathway is to examine the impact of community factors, including stressors, on health, since they occur throughout the course of people's lives and can be transferred across generations for those living in poorer communities 7 .

Few studies examining perceived neighborhood aspects and self-rated health have been published with data from low- or medium-income countries 15 . It is important to investigate the impact of neighborhood characteristics on health in such countries. Macintyre et al. 16 (p. 128) noted " a more differentiated picture has tended to emerge, in which rather than there being one single, universal 'area effect on health' there appear to be some area effects on some health outcomes, in some population groups, and in some types of areas".

Florianópolis is located in Southern Brazil with a population of about 400,000 inhabitants and a Gini Index of 0.40 , which is lower that the country average (0.54) 17. However, it still has striking social inequalities, and around $14 \%$ of the population lives in poor housing conditions, distributed in 171 areas of poverty ${ }^{18}$. Furthermore, in the last ten years, the rates of violent death have been increasing 19. Thus, this study aimed to evaluate the association between selfrated health and perceived neighborhood problems, and tested if it remains after adjustment for potential socioeconomic, demographic, healthrelated behaviors, and health status confounders at the individual level.

\section{Data and methods}

Data were derived from the baseline examination of a population-based cohort study called EpiFloripa, which was carried out in Florianópolis, from September 2009 to January 2010 (http:// www.epifloripa.ufsc.br). The city is the capital of the state of Santa Catarina, with a population of 421,240 inhabitants. The sample size was calculated considering the following parameters: prevalence (50\%), 95\% confidence level, a sample error of 3.5 percentage points, a design effect of 2 because of the cluster sample design, and the addition of $25 \%$ to compensate for refusals ( $n=$ 2,016 adults).

We selected 60 of the 420 urban census tracts of the city. All 420 urban census tracts of the city were ranked according to the average monthly income of the head of the family 20 . The census tracts were classified into income deciles. Six tracts were randomly selected from each decile. All the selected census tracts were visited by the fieldwork team, and all occupied houses were enumerated. In order to reduce the variability in the number of households across tracts, some tracts were split and others were aggregated, taking into consideration their income decile and geographic localization. This process resulted in 63 census tracts with 16,755 eligible households. Within each census tract, we systematically selected 18 occupied households.

\section{Eligibility and exclusion criteria}

All adults aged 20-59 years, who were residents in the selected houses, were eligible to participate. 
Individuals who were unable to answer the questionnaire or faced physical or cognitive impairments were excluded. Anthropometric and blood pressure measurements were not obtained from pregnant women. Women who had delivered a baby within the past six months were excluded.

\section{Losses criteria}

We attempted to find all eligible adults in their home on at least four occasions, with at least one visit on weekends and another in the evening.

\section{Data collection}

Before initiating data collection, the questionnaire was pilot tested among individuals $(n=100)$ who were not study participants. All 35 interviewers were trained prior to the fieldwork.

\section{Outcome}

Self-rated health was assessed by the question "Would you rate your health in general as: very good, good, fair, poor, or very poor”. Participants were grouped into those who reported very good or good versus fair, poor, and very poor health 21 .

\section{Individual-level covariates}

The individual covariates included sex, age (years), educational attainment (12 years or more of formal education, 9-11 years, 5-8 years, or 0-4 years), monthly per capita income in Brazilian Reals - BRL (US\$ $1.0=$ BRL 1.7 during the period of data gathering), race/self-reported skin color (white, brown, and black), duration of living in the neighborhood (years, tertiles), body mass index (BMI), smoking status, alcohol abuse, and physical activity.

Anthropometric measurements followed the recommendations of Lohman et al. 22. Body weight was measured twice. The measurements were made using a portable scale (GA.MA Italy Professional, modelo HCM 5110 M) with a capacity of $150 \mathrm{~kg}$, which was calibrated before the training and fieldwork. For the measurement, the individuals wore light clothes. Height was measured twice using a stadiometer made specifically for the study, with an inelastic measuring tape. During the measurement, the individuals were barefoot and in the Frankfurt position, without any adornments and with shoulders, gluteal muscles, and heels touching the wall, and feet placed side by side. Individual height was considered as the average between the two measurements. Observer reliability measures were calculated as recommended by Gore et al. 23 .
Current smoking status was assessed using the categories of no smoker and former smoker (no), and current smoker (yes). The Alcohol Use Disorder Identification Test (AUDIT) was used to identify persons with hazardous and harmful patterns of alcohol consumption 24. Physical activities were assessed according to the leisuretime domain (individuals who did not practice any physical activity during leisure time or who practiced it less than once a week in the three months preceding the interview) 25 .

Common mental disorders were assessed by the Self-Reporting Questionnaire (SRQ-20) 26. Alcohol use, and mental disorders were included as continuous variables.

Persons with chronic diseases were defined as those who indicated they had back pain, arthritis, fibromyalgia, cancer, diabetes, asthma, hypertension, cardiovascular disease, chronic kidney disease, depression, schizophrenia, tuberculosis, tendinitis, cirrhoses and stroke diagnosed by a physician or health professional 27 .

\section{Census tract level variables}

We used the tertiles of the household head mean monthly per capita income from the 2000 Brazilian census (http://www.ibge.gov.br) for each of the 63 census tracts.

\section{Group-level variables}

Neighborhood characteristics were assessed using a questionnaire that included 16 items, adapted from the study by Ellaway et al. 28. For each item the response options were none, some or many problems (related to the specific item) in the neighborhood. For analysis, those options were codded as zero, one, or two, respectively. Considering the changes made in the questionnaire, analyses with factorial analysis were performed to group perceived neighborhood items 29. After factor analysis using polychoric transformation, with orthogonal rotation, items were grouped into two scales: physical problems (garbage, uneven pavements, unpleasant smells, air, water or ground pollution, lack of a safe place for children to play, speeding cars, and lack of urban transport), and social disorder problems (vandalism, burglaries, assaults, murders, drug use, unsafe walking after dark, bad reputation, and problems with the police). Factor loadings, assessment of scale internal consistency, and theoretical considerations oriented the variable grouping process. Cronbach's alpha was calculated to measure the internal consistency of the scales, which was 0.67 and 0.81 for physical and social disorder problems, respectively. These 
constructs explained $79 \%$ of the variance of the investigated items 29.

The neighborhood-level scales used in the analysis derived from empirical Bayesian estimates through three-level models 30,31,32. Level 1 corresponded to item responses within individuals, Level 2 corresponded to persons nested within the neighborhoods, and, Level 3 corresponded to neighborhoods. The intra-neighborhood correlations (ICC) observed were 0.28 and 0.27 for physical problems and social disorder problems, respectively. The neighborhood reliability was 0.95 and 0.96 for physical and social disorder problems, respectively. The scales generated after three-level multilevel analysis were divided into tertiles for analysis 29 .

Census tracts were used as proxy for neighborhoods. Census tracts include a mean of 300 households and were defined by the official agency of population data and statistics in Brazil 20.

\section{Data quality control}

Data quality control consisted of applying a short version of the questionnaire (10 questions) through a telephonic interview with $15 \%$ of the whole sample $(n=248)$. Kappa statistics and intraclass correlation coefficient were calculated to assess reliability.

\section{Statistical analysis}

Univariate and bivariate analyses were performed, taking the complex sample into account (weighted and clustered sample). Multilevel logistic regression models with a random intercept for each tract were used to assess associations of neighborhood characteristics and the odds of fair, poor, and very poor health (henceforth referred to as poor health). Adjustment variables were included in sequential sets 33 . We performed analysis separated for neighborhood perceived physical and social disorder scales. Additionally analyses with all items of the instrument were done. The first model included census tract level income and length of time residing in the same neighborhood. After that, we added all perceived neighborhood problems (group-level variable) - scores generated through previous three level multilevel analysis. In the third model, we added individual demographic variables (gender, age and skin color). In Model 4, we also included individual socioeconomic variables (income, educational attainment), and in Model 5, healthrelated behaviors (smoking, alcohol abuse, and physical activity) were included. The sixth model included additional physical health risk factors (BMI, chronic diseases), and, finally, the seventh model included mental health (common mental disorder). For the dimensions of neighborhood perceived physical and social disorders problems, the last three models were performed. Furthermore, analysis with both scales were performed separately for males and females. Version 12.0 of the Stata software (Stata Corp., College Station, U.S.A.) was used to perform these analyses. Multilevel models were weighted, and model fit was evaluated using the Akaike Information Criterion (AIC) and Bayesian Information Criterion (BIC).

\section{Ethical issues}

The research project was submitted to and approved by the Ethics Committee of Research in Human Subjects of the Federal University in Santa Catarina (n. 351/08). Consent for interviews and for anthropometric and blood pressure measurements and examinations was obtained prior to the study.

\section{Results}

The response rate of the survey was $85.3 \%(1,720$ adults), with a mean of 26.5 , ranging from 10 to 40 per neighborhood. Over half of the sample $(55.5 \%)$ was female, the mean age of the sample was 38.1 years, and $89.9 \%$ were white. The mean duration of living in the same neighborhood was 13.4 years. Most of the subjects were nonsmokers and did not abuse alcohol, had normal weight and at least one self-reported chronic disease (Table 1).

The prevalence of poor self-rated health was $18.8 \%$ (95\%CI: 15.9-21.7\%). Residents of census tracts in the lower and intermediate income tertile reported poorer health than those in the highest tertile after adjustment for length of time in the neighborhood (Table 2, Model 1, OR = 2.32; 95\%CI: $2.24-2.41$ and OR $=1.45$; 95\%CI: $1.40-1.51$, for the lowest and intermediate neighborhood income categories, respectively). These associations were largely unchanged after adjustment for demographic characteristics and neighborhood problems (Table 2, Model 3). They were sharply reduced but remained statistically significant after adjustment for individual socioeconomic characteristics. Further adjustment for physical health status (BMI and chronic conditions variables slightly weakened these associations; Table 3), OR = 1.12 (95\%CI: 0.98-1.06) and $\mathrm{OR}=1.02$ (95\%CI: 0.98-1.06), respectively.

People living in areas with higher levels of neighborhood problems (physical and social disorder scales) reported worse health than those 
Table 1

Selected characteristics of the study sample. Florianópolis, Santa Catarina State, Brazil, 2009.

\begin{tabular}{|c|c|c|c|}
\hline Variables & $\begin{array}{c}\text { Total (\%) } \\
(\mathrm{N}=1,720)\end{array}$ & $\begin{array}{l}\text { Male (\%) } \\
(\mathrm{n}=761)\end{array}$ & $\begin{array}{c}\text { Female (\%) } \\
(\mathrm{n}=959)\end{array}$ \\
\hline \multicolumn{4}{|l|}{ Demographic } \\
\hline \multicolumn{4}{|l|}{ Gender } \\
\hline Male & 44.5 & - & - \\
\hline Female & 55.5 & - & - \\
\hline \multicolumn{4}{|l|}{ Race/Skin color } \\
\hline White & 89.9 & 88.5 & 91.0 \\
\hline Brown & 5.7 & 7.5 & 4.2 \\
\hline Black & 4.4 & 4.0 & 4.8 \\
\hline \multicolumn{4}{|c|}{ Age groups (years) } \\
\hline $20-29$ & 32.7 & 34.8 & 31.0 \\
\hline $30-39$ & 22.9 & 22.8 & 22.9 \\
\hline $40-49$ & 25.0 & 23.7 & 26.0 \\
\hline $50-59$ & 19.4 & 18.6 & 20.1 \\
\hline \multicolumn{4}{|c|}{ Tertiles of neighborhood residence time (years) } \\
\hline $0.00-5.00$ & 37.4 & 39.3 & 36.0 \\
\hline $5.01-16.50$ & 29.7 & 30.2 & 29.4 \\
\hline $16.51-59.00$ & 32.8 & 30.5 & 34.7 \\
\hline \multicolumn{4}{|l|}{ Socioeconomic } \\
\hline \multicolumn{4}{|c|}{ Tertile of family per capita income } \\
\hline Lower & 32.6 & 29.9 & 34.7 \\
\hline Intermediate & 33.3 & 34.4 & 32.4 \\
\hline Higher & 34.1 & 35.7 & 32.9 \\
\hline \multicolumn{4}{|c|}{ Educational attainment (years) } \\
\hline 12 and more & 43.9 & 43.0 & 44.6 \\
\hline $9-11$ & 33.4 & 34.5 & 32.5 \\
\hline $5-8$ & 14.0 & 13.7 & 14.2 \\
\hline $0-4$ & 8.8 & 8.8 & 8.7 \\
\hline \multicolumn{4}{|c|}{ Occupational status } \\
\hline Non manual & 65.1 & 60.2 & 69.0 \\
\hline Manual & 27.6 & 32.2 & 23.9 \\
\hline Other & 7.3 & 7.6 & 7.1 \\
\hline \multicolumn{4}{|c|}{ Health-related behaviors } \\
\hline \multicolumn{4}{|l|}{ Alcohol abuse } \\
\hline No & 81.5 & 70.4 & 90.4 \\
\hline Yes & 18.5 & 29.6 & 9.6 \\
\hline \multicolumn{4}{|l|}{ Current smoking } \\
\hline No & 80.8 & 78.6 & 82.5 \\
\hline Yes & 19.2 & 21.4 & 17.6 \\
\hline \multicolumn{4}{|c|}{ Leisure physical activity } \\
\hline Active & 46.9 & 46.3 & 58.6 \\
\hline Inactive & 53.1 & 53.7 & 41.4 \\
\hline \multicolumn{4}{|l|}{ Health status } \\
\hline \multicolumn{4}{|c|}{ Body mass index $\left(\mathrm{kg} / \mathrm{m}^{2}\right)$} \\
\hline$<25.0$ & 52.8 & 47.9 & 56.9 \\
\hline $25.0-29.9$ & 31.4 & 37.5 & 26.4 \\
\hline$\geq 30.0$ & 15.8 & 14.7 & 16.7 \\
\hline
\end{tabular}

(continues) 


\begin{tabular}{|c|c|c|c|}
\hline Variables & $\begin{array}{c}\text { Total (\%) } \\
(\mathrm{N}=1,720)\end{array}$ & $\begin{array}{l}\text { Male (\%) } \\
(n=761)\end{array}$ & $\begin{array}{c}\text { Female (\%) } \\
(n=959)\end{array}$ \\
\hline \multicolumn{4}{|l|}{ Health status } \\
\hline \multicolumn{4}{|c|}{ Minor psychiatric disorder } \\
\hline No & 85.3 & 92.6 & 79.5 \\
\hline Yes & 14.7 & 7.5 & 20.5 \\
\hline \multicolumn{4}{|c|}{ Chronic diseases } \\
\hline No & 35.9 & 41.0 & 31.7 \\
\hline Yes & 64.2 & 59.0 & 68.3 \\
\hline \multicolumn{4}{|c|}{ Self-rated health } \\
\hline Positive & 81.2 & 84.8 & 78.3 \\
\hline Negative & 18.8 & 15.2 & 21.7 \\
\hline
\end{tabular}

Table 2

Odds ratios of poor self-rated health, associated with census tract level income and neighborhood problem scales. Florianópolis, Santa Catarina State, Brazil, 2009

\begin{tabular}{|c|c|c|c|c|c|c|c|}
\hline & $\begin{array}{c}\text { Model } 1 \\
\text { [OR }(95 \% \mathrm{Cl})]\end{array}$ & $\begin{array}{c}\text { Model } 2 \\
\text { [OR }(95 \% \mathrm{Cl})]\end{array}$ & $\begin{array}{c}\text { Model } 3 \\
\text { [OR }(95 \% \mathrm{Cl})]\end{array}$ & $\begin{array}{c}\text { Model } 4 \\
\text { [OR }(95 \% \mathrm{Cl})]\end{array}$ & $\begin{array}{c}\text { Model } 5 \\
\text { [OR }(95 \% \mathrm{Cl})]\end{array}$ & $\begin{array}{c}\text { Model } 6 \\
\text { [OR }(95 \% \mathrm{Cl})]\end{array}$ & $\begin{array}{c}\text { Model } 7 \\
{[\text { OR }(95 \% \mathrm{Cl})]}\end{array}$ \\
\hline \multicolumn{8}{|c|}{ Census tract income } \\
\hline Higher & 1.00 & 1.00 & 1.00 & 1.00 & 1.00 & 1.00 & 1.00 \\
\hline Intermediate & $1.45(1.40-1.51)$ & $1.39(1.33-1.45)$ & $1.52(1.46-1.59)$ & $1.07(1.03-1.12)$ & $1.08(1.03-1.13)$ & $1.00(0.96-1.05)$ & $1.01(0.97-1.05)$ \\
\hline Lower & $2.32(2.24-2.41)$ & $2.27(2.19-2.36)$ & $2.41(2.32-2.51)$ & $1.21(1.15-1.26)$ & $1.19(1.14-1.25)$ & $1.11(1.06-1.15)$ & $1.09(1.04-1.13)$ \\
\hline \multicolumn{8}{|c|}{$\begin{array}{l}\text { All neighborhood } \\
\text { problems * }\end{array}$} \\
\hline Lower & & 1.00 & 1.00 & 1.00 & 1.00 & 1.00 & 1.00 \\
\hline Intermediate & & $1.30(1.27-1.34)$ & $1.41(1.36-1.45)$ & $1.49(1.44-1.54)$ & $1.54(1.49-1.59)$ & $1.55(1.63-1.75)$ & $1.40(1.35-1.45)$ \\
\hline Higher & & $1.47(1.43-1.52)$ & $1.56(1.51-1.61)$ & $1.66(1.61-1.72)$ & $1.71(1.65-1.78)$ & $1.69(1.49-1.60)$ & $1.17(1.13-1.22)$ \\
\hline AIC & 165343.6 & 164750.8 & 157257.8 & 146018.5 & 143306.5 & 131073.9 & 118683.5 \\
\hline $\mathrm{BIC}$ & 165370.8 & 164797.9 & 157312.3 & 146083.6 & 143380.8 & 131165.5 & 118780.2 \\
\hline
\end{tabular}

95\% Cl: 95\% confidence interval; AIC: Akaike Information Criterion; BIC: Bayesian Information Criterion; OR: odds ratio.

Model 1: census tract level income and length of time residing in neighborhood; Model 2: census tract level income, length of time residing neighborhood and neighborhood problems; Model 3: census tract level income, length of time residing in neighborhood and demographic variables (age, gender, skin color); Model 4: census tract level income, length of time residing in neighborhood, demographic (age, gender, skin color) and socioeconomic (income, schooling) variables; Model 5: census tract level income, length of time residing in neighborhood, demographic (age, gender, skin color), socioeconomic (income, schooling) and health related variables (physical activity, smoking, alcohol use); Model 6: census tract level income, length of time residing in neighborhood, demographic variables (age, gender, skin color), socioeconomic (income, schooling), health related variables (physical activity, smoking, alcohol use) and physical health status variables (body mass index and chronic disease); Model 7: census tract level income, length of time residing in neighborhood, demographic variables (age, gender, skin color), socioeconomic (income, schooling), health related variables (physical activity, smoking, alcohol use), physical health status (body mass index and chronic disease) and mental health status (common mental disorders).

* Both physical and social disorder problem scales.

living in areas with less problems, even after adjustment for neighborhood income, demographic characteristics, and socioeconomic factors (Table 2, Model 4, OR = 1.66; 95\%CI: 1.61-1.72 and OR = 1.49; 95\%CI: 1.44-1.54). These associations were slightly weakened only after adjustment for mental health variables $(\mathrm{OR}=1.40$; $95 \% \mathrm{CI}$ : 1.35 1.45 and $\mathrm{OR}=1.17$; $95 \% \mathrm{CI}$ : $1.13-1.22$ for intermediate and highest tertile, respectively).

Table 3 shows separately the results of similar analyses including neighborhood problems related to physical and social disorders (adjusted 
Odds ratios of poor self-rated health associated with census tract level income and perceived neighborhood physical problems and neighborhood socia disorder scale. Florianópolis, Santa Catarina State, Brazil, 2009

\begin{tabular}{|c|c|c|c|c|c|c|}
\hline & $\begin{array}{c}\text { Model } 1 \\
\text { [OR }(95 \% \mathrm{Cl})]\end{array}$ & $\begin{array}{c}\text { Model } 2 \\
\text { [OR }(95 \% \mathrm{Cl})]\end{array}$ & $\begin{array}{c}\text { Model } 3 \\
{[\text { OR }(95 \% \mathrm{Cl})]}\end{array}$ & $\begin{array}{c}\text { Model } 1 \\
\text { [OR }(95 \% \mathrm{Cl})]\end{array}$ & $\begin{array}{c}\text { Model } 2 \\
\text { [OR }(95 \% \mathrm{Cl})]\end{array}$ & $\begin{array}{c}\text { Model } 3 \\
\text { [OR }(95 \% \mathrm{Cl})]\end{array}$ \\
\hline \multicolumn{7}{|c|}{ Census tract income } \\
\hline Higher & 1.00 & 1.00 & & 1.00 & 1.00 & \\
\hline Intermediate & $1.01(0.97-1.06)$ & $0.97(0.93-1.01)$ & $0.98(0.94-1.02)$ & $1.10(1.05-1.15)$ & $1.02(0.98-1.06)$ & $1.00(0.96-1.04)$ \\
\hline Lower & 1.09 (1.04-1.15) & $1.04(0.99-1.08)$ & 1.05 (1.01-1.09) & $1.21(1.15-1.26)$ & $1.12(1.07-1.16)$ & $1.07(1.02-1.12)$ \\
\hline \multicolumn{7}{|c|}{ Physical problems } \\
\hline Lower & 1.00 & 1.00 & 1.00 & & & \\
\hline Intermediate & $1.87(1.80-1.93)$ & $1.69(1.63-1.75)$ & $1.44(1.39-1.49)$ & & & \\
\hline Higher & $2.02(1.95-2.10)$ & $1.81(1.74-1.88)$ & $1.23(1.19-1.28)$ & & & \\
\hline $\mathrm{AIC}$ & $14,2610.7$ & $13,0854.2$ & $11,8624.8$ & & & \\
\hline $\mathrm{BIC}$ & $14,2692.0$ & $13,0945.8$ & $11,8721.5$ & & & \\
\hline \multicolumn{7}{|c|}{ Social disorder problems } \\
\hline Lower & & & & 1.00 & 1.00 & 1.00 \\
\hline Intermediate & & & & 1.09 (1.05-1.13) & $1.23(1.18-1.27)$ & $1.19(1.15-1.24)$ \\
\hline Higher & & & & $1.41(1.37-1.46)$ & $1.43(1.38-1.48)$ & $1.07(1.03-1.11)$ \\
\hline $\mathrm{AIC}$ & & & & $14,3869.7$ & $13,1592.4$ & $11,8889.4$ \\
\hline $\mathrm{BIC}$ & & & & $14,3951.0$ & $13,1684.0$ & $11,8986.0$ \\
\hline
\end{tabular}

95\% Cl: 95\% confidence interval; AIC: Akaike Information Criterion; BIC: Bayesian Information Criterion; OR: odds ratio.

Model 1: census tract level income, length of time residing in neighborhood, demographic variables (age, gender, skin color), socioeconomic (income, schooling) and health related variables (physical activity, smoking, alcohol use); Model 2: census tract level income, length of time residing in neighborhood, demographic variables (age, gender, skin color), socioeconomic (income, schooling), health related variables (physical activity, smoking, alcohol use) and physical health status (body mass index and chronic disease); Model 3: census tract level income, length of time residing in neighborhood, demographic variables (age, gender, skin color), socioeconomic (income, schooling), health related variables (physical activity, smoking, alcohol use), physical health status (body mass index and chronic disease) and mental health status (common mental disorders).

for census tract income and covariates). In general perceived neighborhood physical problems were more strongly associated with self-rated health than the perceived social disorder problems (OR for lowest and middle tertiles after adjustment for sociodemograhic characteristics 1.97 and 1.82 for physical problems and 1.40 and 1.08 for social disorders problems). In both cases adjustment for mental health slightly reduced the associations although they still remained statistically significant.

The women in the intermediate tertile of neighborhood perceived physical problems had always higher odds of reporting poor health than men: in the fully adjusted model (Model 3 ) results were 1.65 and 1.21 for women and men, respectively. However, on the higher tertile of physical problems the chances of reporting poor health were quite similar in both genders (Table 4 ).

In the last model, men that reported a higher level of perceived neighborhood social disorder problems had better self-rated health than those in the lower and intermediate tertile of problems.
In women, the positive association between neighborhood social disorder problems and poorer health remained, although with closer odds in intermediate and higher tertiles of problems, than in previous adjusted models (Table 5).

In each of the investigated models, the AIC and BIC values exhibited an important reduction for all the scales analyzed (Tables 2, 3 and 4).

\section{Discussion}

This study investigated how perceived neighborhood problems and census tract level income are associated with self-rated health, after controlling for sociodemographic, health-related behaviors, and physical and mental health status variables using the data from a Brazilian city, Florianópolis. Despite all the adjustments, the association between self-rated health and perceived neighborhood problems remained statistically significant for the scales of both physical and social disorder problems. In some models, 
Table 4

Odds ratios of poor self-rated health associated with census tract level income and perceived neighborhood physical problems by gender. Florianópolis, Santa Catarina State, Brazil, 2009.

\begin{tabular}{|c|c|c|c|c|c|c|}
\hline & \multicolumn{3}{|c|}{ Males } & \multicolumn{3}{|c|}{ Females } \\
\hline & $\begin{array}{c}\text { Model } 1 \\
{[\mathrm{OR}(95 \% \mathrm{Cl})]}\end{array}$ & $\begin{array}{c}\text { Model } 2 \\
\text { [OR }(95 \% \mathrm{Cl})]\end{array}$ & $\begin{array}{c}\text { Model } 3 \\
\text { [OR }(95 \% \mathrm{Cl})]\end{array}$ & $\begin{array}{c}\text { Model } 1 \\
{[\text { OR }(95 \% \mathrm{Cl})]}\end{array}$ & $\begin{array}{c}\text { Model } 2 \\
\text { [OR }(95 \% \mathrm{Cl})]\end{array}$ & $\begin{array}{c}\text { Model } 3 \\
\text { [OR }(95 \% \mathrm{Cl})]\end{array}$ \\
\hline \multicolumn{7}{|c|}{ Census tract income } \\
\hline Higher & 1.00 & 1.00 & 1.00 & 1.00 & 1.00 & 1.00 \\
\hline Intermediate & $1.21(1,13-1.28)$ & $1.10(1.03-1.17)$ & $1.19(1.11-1.27)$ & $0.92(0.87-097)$ & $0.90(0.85-0.95)$ & $0.87(0.82-0.91)$ \\
\hline Lower & $1.12(1.05-1.20)$ & $1.18(1.01-1.26)$ & $1.20(1.11-1.28)$ & $1.06(1.00-1.13)$ & $0.92(0.87-0.97)$ & $0.95(0.90-1.00)$ \\
\hline \multicolumn{7}{|c|}{ Physical problems } \\
\hline Lower & 1.00 & 1.00 & 1.00 & 1.00 & 1.00 & 1.00 \\
\hline Intermediate & $1.62(1.54-1.72)$ & $1.39(1.31-1.47)$ & $1.21(1.14-1.29)$ & $2.00(1.91-2.10)$ & $1.82(1.74-1.91)$ & $1.65(1.57-1.73)$ \\
\hline Higher & $2.13(2.02-2.25)$ & $1.77(1.67-1.87)$ & $1.27(1.19-1.34)$ & $1.91(1.82-2.00)$ & $1.81(1.72-1.90)$ & $1.26(1.20-1.33)$ \\
\hline AIC & $54,817.85$ & $51,158.36$ & $47,836.15$ & $86,631.42$ & $78,045.33$ & $68,905.69$ \\
\hline $\mathrm{BIC}$ & $54,882.29$ & $51,231.78$ & $47,913.95$ & $86,699.12$ & $78,122.02$ & $68,986.81$ \\
\hline
\end{tabular}

95\% Cl: 95\% confidence interval; AIC: Akaike Information Criterion; BIC: Bayesian Information Criterion; OR: odds ratio.

Model 1: census tract level income, length of time residing in neighborhood, demographic variables (age, gender, skin color), socioeconomic (income, schooling) and health related variables (physical activity, smoking, alcohol use); Model 2: census tract level income, length of time residing in neighborhood, demographic variables (age, gender, skin color), socioeconomic (income, schooling), health related variables (physical activity, smoking, alcohol use) and physical health status (body mass index and chronic disease); Model 3: census tract level income, length of time residing in neighborhood, demographic variables (age, gender, skin color), socioeconomic (income, schooling), health related variables (physical activity, smoking, alcohol use), physical health status (body mass index and chronic disease) and mental health status (common mental disorders)

Table 5

Odds ratios of poor self-rated health associated with census tract level income and perceived neighboorhod social disorder problems by gender. Florianópolis, Santa Catarina State, Brazil, 2009.

\begin{tabular}{|c|c|c|c|c|c|c|}
\hline & \multicolumn{3}{|c|}{ Males } & \multicolumn{3}{|c|}{ Females } \\
\hline & $\begin{array}{c}\text { Model } 1 \\
\text { [OR }(95 \% \mathrm{Cl})]\end{array}$ & $\begin{array}{c}\text { Model } 2 \\
\text { [OR }(95 \% \mathrm{Cl})]\end{array}$ & $\begin{array}{c}\text { Model } 3 \\
\text { [OR }(95 \% \mathrm{Cl})]\end{array}$ & $\begin{array}{c}\text { Model } 1 \\
{[\text { OR }(95 \% \mathrm{Cl})]}\end{array}$ & $\begin{array}{c}\text { Model } 2 \\
\text { [OR }(95 \% \mathrm{Cl})]\end{array}$ & $\begin{array}{c}\text { Model } 3 \\
\text { [OR }(95 \% \mathrm{Cl})]\end{array}$ \\
\hline \multicolumn{7}{|l|}{ Census tract income } \\
\hline Higher & 1.00 & 1.00 & 1.00 & 1.00 & 1.00 & 1.00 \\
\hline Intermediate & $1.36(1.28-1.45)$ & $1.18(1.11-1.26)$ & $1.27(1.19-1.36)$ & $0.97(0.92-1.03)$ & $0.94(0.89-0.99)$ & $0.86(0.82-0.91)$ \\
\hline Lower & $1.29(1.21-1.38)$ & $1.29(1.21-1.38)$ & $1.25(1.17-1.34)$ & $1.11(1.05-1.18)$ & $0.96(0.91-1.01)$ & $0.94(0.89-0.99)$ \\
\hline \multicolumn{7}{|l|}{ Social disorder } \\
\hline Lower & 1.00 & 1.00 & 1.00 & 1.00 & 1.00 & 1.00 \\
\hline Intermediate & $1.19(1.13-1.26)$ & $1.29(1.22-1.36)$ & $1.10(1.04-1.17)$ & $1.00(0.95-1.04)$ & $1.16(1.10-1.21)$ & $1.31(1.25-1.38)$ \\
\hline Higher & $1.04(0.98-1.10)$ & $1.08(1.01-1.34)$ & $0.82(0.77-0.87)$ & $1.67(1.60-1.74)$ & $1.74(1.67-1.82)$ & $1.37(1.31-1.48)$ \\
\hline $\mathrm{AIC}$ & 55531.47 & 51446.1 & 47787.2 & 86928.8 & 78165.1 & 69139.17 \\
\hline $\mathrm{BIC}$ & 55595.87 & 51519.48 & 47864.96 & 86996.51 & 78241.8 & 69220.29 \\
\hline
\end{tabular}

95\% Cl: 95\% confidence interval; AIC: Akaike Information Criterion; BIC: Bayesian Information Criterion; OR: odds ratio.

Model 1: census tract level income, length of time residing in neighborhood, demographic variables (age, gender, skin color), socioeconomic (income, schooling) and health related variables (physical activity, smoking, alcohol use); Model 2: census tract level income, length of time residing in neighborhood, demographic variables (age, gender, skin color), socioeconomic (income, schooling), health related variables (physical activity, smoking, alcohol use) and physical health status (body mass index and chronic disease); Model 3: census tract level income, length of time residing in neighborhood, demographic variables (age, gender, skin color), socioeconomic (income, schooling), health related variables (physical activity, smoking, alcohol use), physical health status (body mass index and chronic disease) and mental health status (common mental disorders). 
the strength of association between the variables was even reinforced.

These findings confirm previous studies about the relationship between perceived neighborhood problems and self-rated health 34,35,36. Poortinga et al. 35 found that neighborhood quality, neighborhood disorder, and deprivation had the strongest associations with poor health at the neighborhood level 35. Among older adults in Bogotá, Colombia, Parra et al. 37 observed that perceived neighborhood characteristics, such as safety from traffic and having safe parks, were positively associated with self-rated health.

The perception of neighborhood problems may affect health through different pathways, including individual socioeconomic levels, demographic variables, as well as adopting healthrelated behaviors, and psychosocial and health status variables 38 . Cumulative and compounding aspects of local environments that heighten feelings of insecurity and anxiety may be mechanisms that affect health through the living environment 39 . The impact of neighborhood conditions on health is likely to be modified by individual-level characteristics that make them more vulnerable to adverse neighborhood conditions, while others may have the personal and financial resources that allow them to overcome deficiencies or hazards in their neighborhoods 14 .

In the EpiFloripa study population, the adjustment for demographic, socioeconomic, and health-related behaviors increased the strength of association between perceived neighborhood physical problems and self-rated health. Areas with poorer quality residential environments may affect health by limiting opportunities for physical activity, such as walking, playing and sports, or through the increase in stress from threatening environmental cues ${ }^{36}$. In fact, unhealthy behaviors, such as smoking ${ }^{40}$, alcohol abuse, physical inactivity, and poor food patterns, may be part of an individual's response to a stressful neighborhood 14. In most of the previous studies, the association between perceived neighborhood problems and health are substantially attenuated when controlling for individual and collective socioeconomic status 35 , similar to those observed in relation to census tract level income in the EpiFloripa study population. This suggests that individual socioeconomic variables were important co-variables in association between self-rated health and neighborhood income.

In the studied population, those groups who perceived higher levels of physical problems in the neighborhood, showed reduced association between the variables, after adjusting for health status and minor psychiatric disorders. Further- more, after adjustment for health status variables, the association in the group with higher tertiles of neighborhood problems was lower than that observed in the intermediate tertile. This might probably indicate that the association between self-rated health and perceived neighborhood problems in the group with the highest tertile of problems can be influenced by physical and mental health status co-variables. In fact, residing in a disadvantaged neighborhood may be associated with barriers to the management of a chronic condition. People with chronic conditions can find more problems in managing undesirable neighborhood characteristics, and have more difficulties in finding adequate treatment 41 .

On the social disorder scale, an association between self-rated health and perceived neighborhood problems was even reinforced after adjustment for individual socioeconomic levels. This may reflect as overreaction to criminality and physical security in Brazilian high-income groups, since violence-related mortality rates are higher in low-income people 15 .

Wen et al. 38 pointed out that the perceived neighborhood environment on health are partially explained by the psychosocial factors of loneliness, depression, hostility and stress, but not by perceived social supports or social networks. In our study, individual characteristics influenced the association between neighborhood perceived problems and self-rated health, in different magnitudes and in some analyses, the association was inverted among investigated variables. After adjusting for mental health variables, the association clearly decreased. In a Japanese study, it was observed that when controlling for personality traits, the odds for reporting poor health in response to negative neighborhood assessments declined, but remained highly significant 13 .

Ross \& Mirowsky 42 found that residents of disadvantaged neighborhoods have worse health (worse self-reported health and physical functioning and more chronic conditions) than those of more advantaged neighborhoods. The association was entirely mediated by perceived neighborhood disorders and the resulting fear, and not by the limitation of outdoor physical activities. The daily stress associated with living in a neighborhood where danger, trouble, crime and incivility are common appeared to be damaging to health.

Beyond the cross-sectional implications of our findings, it is important to take into account the several reinforcing mechanisms that explain the processes through which neighborhood physical and social disorder problems could contribute to health and health inequalities 14 . 
It has also been argued that individuals may select (or be selected into) their place of residence (or neighborhood) based on their health or predisposition to certain behaviors. For instance, mental illness may result in downward social mobility and may ultimately cause depressed persons to live in neighborhoods with greater physical disorders 14 .

By using area-level aggregates of survey responses to characterize neighborhoods, respondents in each neighborhood are viewed as informants of the conditions in their area. Although this approach is useful, it has three limitations. One limitation is that reporting bias may create spurious associations between self-reported neighborhood conditions and self-reported health outcomes (source bias) 35 . The second limitation is that the neighborhood-level constructs are measured on the basis of reports made by individuals, and although individual reports are undoubtedly influenced by objective reality, they are also influenced by personal factors and perceptions, which may introduce measurement error 31 . To the extent that people's perceptions reflect reality, averaging responses across multiple persons within a neighborhood may reduce measurement error due to individual subjectivity 31,32. Nevertheless, we cannot rule out that the observed association between neighborhood perceptions and self-rated health may be at least partly spurious, because these two self-reported measures are highly subjective 13 . The third limitation is related to the sample size, not designed to be representative of each census tract.

Furthermore, the ability to investigate gender differences in our study may not be high, mainly in some neighborhoods, with a small number of observations. The approach applied by us for building the scales values, the empirical Bayesian estimates, deals with the above-mentioned problem, because it allows for borrowing strengths across neighborhoods and reduces estimates for neighborhoods with few observations towards the overall mean 31,32 .
Despite the limitations of the chosen approach, the associations between neighborhood problems and self-rated health were strong, and remained strong even after adjustment for all the investigated variables sets. However, longitudinal studies are required to chart the change over time and show whether a lag effect of the change in the local environment on health status exists 36. Future studies can examine whether subjective perceptions are simply reflections of objective characteristics, or play their own role as mediators or possibly moderators 43 . Furthermore, other studies can collect neighborhood objective measures as systematic social observations, and use other methods to deal with those measures 44

Finally, our findings confirm the strong association between self-rated health and perceived neighborhood problems, and this association was little reduced after adjusting for health status related variables. Furthermore, we noticed important gender interactions in the association of the variables. Neighborhood social disorder problems influenced women more than men with respect to self-rated health, while the physical problems scale had a similar impact on both genders, though was slightly more pronounced among men.

The features of the neighborhood environment are noted to be associated with self-rated health, and may act as indicators of important causal pathways that could provide a focus for public health intervention strategies. Operationalizing specific measures of the characteristics of local areas hypothesized to be important for living a healthy life provides a more focused approach than general measures of deprivation in the search for area effects 26 . Thus, more emphasis should be given to residents' perceptions of physical environmental factors in the formulation of local public health polices 45 . 


\section{Resumen}

Los problemas en barrios representan fuentes de estrés crónico que pueden aumentar el riesgo de autoevaluación de salud negativa. En la ciudad de Florianópolis, Santa Catarina, Brasil, se examinó la asociación entre la renta de las circunscripciones censales y los problemas en barrios con la autoevaluación de salud entre 1.720 adultos. Se estimaron las razones de momios (RM) y sus intervalos de confianza de un 95\% de autoevaluación de salud negativa (IC95\%) mediante modelos multiniveles. Los residentes en circunscripciones censales de renta baja e intermedia reporta ron peor salud que aquellos del tercil más elevado. La razón de momios al informar peor salud fue un 2,44 (IC95\%: 2,35-2,54) en el tercil con más problemas de desórdenes sociales en el barrio (ajustado para la salud mental). La posibilidad de informar una peor salud con problemas en el barrio varió de 1,07 (IC95\%: 1,03-1,11) a 2,02 (IC95\%: 1,95-2,10) para el tercil más elevado de desorden social (salud física) y problemas físicos en el barrio (relacionados con la salud). La percepción de problemas en el barrio se asoció independientemente a una salud peor, y debe ser considerada por aquellos que elaboran políticas.

Vivienda; Distribución Espacial de la Población; Factores Socioeconómicos; Salud Urbana

\section{Contributors}

D. A. Höfelmann participated in the study design, including data quality control, supervised the fieldwork activities, performed the multilevel analysis of the data, and was responsible for the study's analytic strategy. A. V. Diez Roux participated in the manuscript conception, helped with the analytic strategy, critically reviewed the manuscript and helped with statistical analysis. J. L. F. Antunes collaborated in the literature review, helped with the analytic strategy, and instructed multilevel analysis of the data. M. A. Peres participated in the study design, the study's analytic strategy, and in the conception and writing of the manuscript. All the authors have contributed to the writing of the article and reviewed the final version.

\section{Acknowledgments}

We thank Dr. Nilza Nunes da Silva at the Department of Epidemiology, School of Public Health of the University of São Paulo, São Paulo, Brazil, for her advice on sampling procedures. We would like to thank the Brazilian Institute of Geography and Statistics (IBGE) and the Florianópolis Health Authority staff for their useful help with the practical aspects of the study. This paper is based on the EpiFloripa Adults 2009 - Florianópolis Adults Health Survey.

\section{References}

1. Lima-Costa MF, Cesar CC, Chor D, Proietti FA. Selfrated health compared with objectively measured health status as a tool for mortality risk screening in older adults: 10-year follow-up of the Bambui Cohort Study of Aging. Am J Epidemiol 2012; 175:228-35.

2. Idler EL, Benyamini Y. Self-rated health and mortality: a review of twenty-seven community studies. J Health Soc Behav 1997; 38:21-37.

3. Manderbacka K, Lahelma E, Martikainen P. Examining the continuity of self-rated health. Int J Epidemiol 1998; 27:208-13.
4. Szwarcwald CL, Souza-Júnior PR, Esteves MAP, Damacena GN, Viacava F. Socio-demographic determinants of self-rated health in Brazil. Cad Saúde Pública 2005; 21 Suppl:S54-64.

5. Foraker RE, Rose KM, Chang PP, McNeill AM, Suchindran CM, Selvin E, et al. Socioeconomic status and the trajectory of self-rated health. Age Ageing 2011; 40:706-11.

6. van Raalte AA, Kunst AE, Lundberg O, Leinsalu M, Martikainen P, Artnik B, et al. The contribution of educational inequalities to lifespan variation. Popul Health Metr 2012; 10:3 
7. Steptoe A, Feldman PJ. Neighborhood problems as sources of chronic stress: development of a measure of neighborhood problems, and associations with socioeconomic status and health. Ann Behav Med 2001; 23:177-85.

8. Poortinga W, Dunstan FD, Fone DL. Neighbourhood deprivation and self-rated health: the role of perceptions of the neighbourhood and of housing problems. Health Place 2008; 14:562-75.

9. Santos SM. A importância do contexto social de moradia na auto-avaliação de saúde [Doctoral Dissertation]. Rio de Janeiro: Escola Nacional de Saúde Pública Sergio Arouca, Fundação Oswaldo Cruz; 2008.

10. Yen IH, Kaplan GA. Poverty area residence and changes in depression and perceived health status: evidence from the Alameda County Study. Int J Epidemiol 1999; 28:90-4.

11. Gapen M, Cross D, Ortigo K, Graham A, Johnson E, Evces M, et al. Perceived neighborhood disorder, community cohesion, and PTSD symptoms among low-income African Americans in an urban health setting. Am J Orthopsychiatry 2011; 81:31-7.

12. Mair C, Kaplan GA, Everson-Rose SA. Are there hopeless neighborhoods? An exploration of environmental associations between individual-level feelings of hopelessness and neighborhood characteristics. Health Place 2012; 18:434-9.

13. Oshio T, Urakawa K. Neighborhood perceptions, self-rated health, and personality traits: evidence from Japan. Tokyo: Institute of Economic Research, Hitotsubashi University, 2011.

14. Diez Roux A, Mair C. Neighborhoods and health. Ann N Y Acad Sci 2010; 1186:125-45.

15. Marín-León L, Oliveira HB, Barros MBA, Dalgalarrondo P, Botega NJ. Percepção dos problemas da comunidade: influência de fatores sócio-demográficos e de saúde mental. Cad Saúde Pública 2007; 23:1089-97.

16. Macintyre S, Ellaway A, Cummins S. Place effects on health: how can we conceptualise, operationalise and measure them? Soc Sci Med 2002; 55: 125-39.

17. Instituto Brasileiro de Geografia e Estatística. Cidades. v. 2011. Rio de Janeiro: Instituto Brasileiro de Geografia e Estatística; 2010.

18. Dias L, Sugai M, Pereira. Planejamento e gestão do território. Escalas, conflitos e incertezas. In: Anais do XIII Encontro Nacional da ANPUR; 2009. http://www.anpur.org.br/revista/rbeur/index. $\mathrm{php} / \mathrm{anais} / \mathrm{issue} / \mathrm{view} / 99$.

19. Waiselfisz J. Mapa da violência 2012. Os novos padrões da violência homicida no Brasil. São Paulo: Sanghari; 2011.

20. Instituto Brasileiro de Geografia e Estatística. Censo demográfico 2000. Agregado por setores censitários dos resultados do universo. Rio de Janeiro: Instituto Brasileiro de Geografia e Estatística; 2003.
21. World Health Organization. World Health Survey 2002: individual questionnaire. Geneva: World Health Organization; 2002.

22. Lohman T, Roche A, Martorell R. Anthropometric standardization reference manual. Champaign: Human Kinetics Books; 1988.

23. Gore C, Norton K, Olds T. Accreditation in anthropometry: an Australian model. In: Norton K, Olds T, editors. Anthropometric. Sydney: University of New South Wales Press; 1996. p. 395-411.

24. World Health Organization. The alcohol use disorder indentification test: guideline for use in primary care. Geneva: World Health Organization; 2001.

25. Florindo AA, Hallal PC, Moura EC, Malta DC. Practice of physical activities and associated factors in adults, Brazil, 2006. Rev Saúde Pública 2009; 43 Suppl 2:65-73.

26. World Health Organization. A user's guide to the self reporting questionnaire (SRQ). Geneva: World Health Organization; 1994.

27. Instituto Brasileiro de Geografia e Estatística. Pesquisa Nacional por Amostra de Domicílios, 2009 v. 2010. Brasília: Instituto Brasileiro de Geografia e Estatística; 2009.

28. Ellaway A, Macintyre S, Kearns A. Perceptions of place and health in socially contrasting neighbourhoods. Urban Stud 2001; 38:2299-316.

29. Höfelmann DA, Diez-Roux AV, Antunes JLF, Peres MA. Perceived neighborhood problems: multilevel analysis to evaluate psychometric properties in a Southern adult Brazilian population. BMC Public Health 2013; 13:1085.

30. Friche AA, Diez-Roux AV, Cesar CC, Xavier CC, Proietti FA, Caiaffa WT. Assessing the psychometric and ecometric properties of neighborhood scales in developing countries: Saude em Beaga Study, Belo Horizonte, Brazil, 2008-2009. J Urban Health 2012; 90:246-61

31. Mujahid MS, Diez Roux AV, Morenoff JD, Raghunathan T. Assessing the measurement properties of neighborhood scales: from psychometrics to ecometrics. Am J Epidemiol 2007; 165:858-67.

32. Raudenbush S, Bryk A. Three-level models. Hierarchical linear models: applications and data analysis methods. 2nd Ed. Thousand Oaks: Sage Publications; 2002

33. Victora CG, Huttly SR, Fuchs SC, Olinto MT. The role of conceptual frameworks in epidemiological analysis: a hierarchical approach. Int J Epidemiol 1997; 26:224-7.

34. Pampalon R, Hamel D, De Koninck M, Disant MJ. Perception of place and health: differences between neighbourhoods in the Quebec City region. Soc Sci Med 2007; 65:95-111.

35. Poortinga W, Dunstan FD, Fone DL. Perceptions of the neighbourhood environment and self rated health: a multilevel analysis of the Caerphilly Health and Social Needs Study. BMC Public Health 2007; 7:285. 
36. Cummins S, Stafford M, Macintyre S, Marmot M, Ellaway A. Neighbourhood environment and its association with self rated health: evidence from Scotland and England. J Epidemiol Community Health 2005; 59:207-13.

37. Parra DC, Gomez LF, Sarmiento OL, Buchner D, Brownson R, Schimd T, et al. Perceived and objective neighborhood environment attributes and health related quality of life among the elderly in Bogota, Colombia. Soc Sci Med 2010; 70:1070-6.

38. Wen M, Hawkley LC, Cacioppo JT. Objective and perceived neighborhood environment, individual SES and psychosocial factors, and self-rated health: an analysis of older adults in Cook County, Illinois. Soc Sci Med 2006; 63:2575-90.

39. Warr D, Feldman P, Tacticos T, Kelaher M. Sources of stress in impoverished neighbourhoods: insights into links between neighbourhood environments and health. Aust N Z J Public Health 2009; 33:25-33.

40. van Lenthe FJ, Mackenbach JP. Neighbourhood and individual socioeconomic inequalities in smoking: the role of physical neighbourhood stressors. J Epidemiol Community Health 2006; 60:699-705.
41. Brown AF, Ang A, Pebley AR. The relationship between neighborhood characteristics and self-rated health for adults with chronic conditions. Am J Public Health 2007; 97:926-32.

42. Ross CE, Mirowsky J. Neighborhood disadvantage, disorder, and health. J Health Soc Behav 2001; 42:258-76.

43. Roh S, Jang Y, Chiriboga DA, Kwag KH, Cho S, Bernstein K. Perceived neighborhood environment affecting physical and mental health: a study with Korean American older adults in New York City. J Immigr Minor Health 2011; 13:1005-12.

44. Proietti F, Oliveira C, Ferreira R, Ferreira A, Caiaffa W. Unidade de contexto e observação social sistemática em saúde: conceitos e métodos. Physis (Rio J.) 2008; 18:469-82.

45. Wilson K, Elliott S, Law M, Eyles J, Jerrett M, KellerOlaman S. Linking perceptions of neighbourhood to health in Hamilton, Canada. J Epidemiol Community Health 2004; 58:192-8.

Submitted on 13/Dec/2013

Final version resubmitted on 10/May/2014

Approved on 11/Jul/2014 